Yelena Kozmina*

\section{Классический детектив в свете современной генологии}

DOI: http://dx.doi.org/10.12775/LC.2021.035

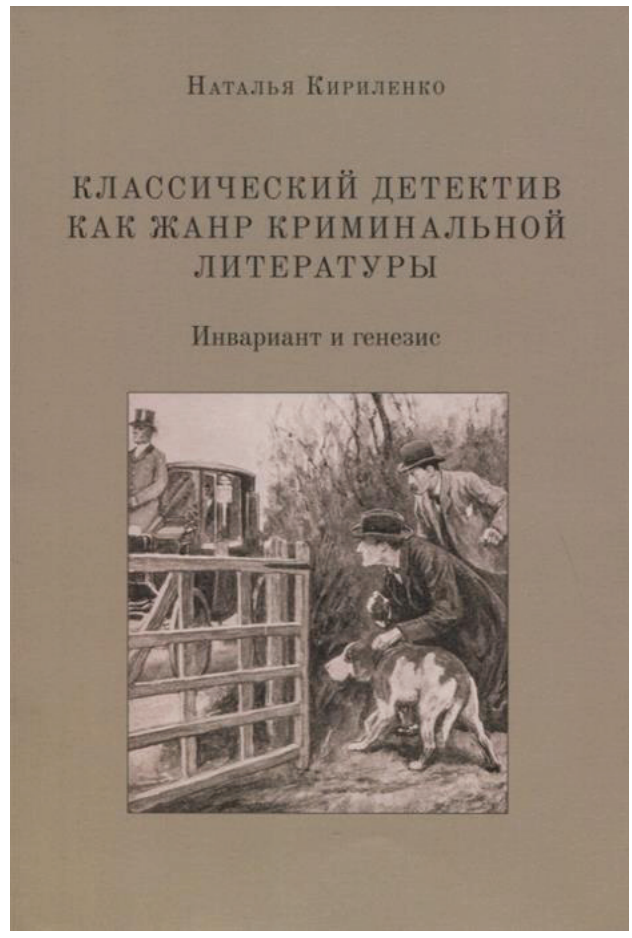

Книга Натальи Кириленко Классический детектив как жанр криминальной митературы: инвариант и генезис вышла

\footnotetext{
* Елена Козьмина

Доктор филологических наук, главный научный сотрудник Центра научного проектирования Управления по научной работе Российского государственного гуманитарного университета (Москва), профессор Уральского федерального университета имени первого Президента России Б. Н. Ельцина (Екатеринбург).

E-mail: klen063@gmail.com | ORCID: 00000001-6226-7032.
}

в 2020 году; а чуть ранее, в 2017 году, в серии «Исследования культуры» ИзАательского Аома ВШЭ была опубликована монография Петра Моисеева на схожую тему под названием Поэтика детектива, а в 2019 под редакцией Киримла Чекалова и Марии Ненароковой вышла в свет Поэтика зарубежного классического детектива (Москва: ИМАИ РАН). Это означает, что тема криминальной митературы и ее главного жанра - детектива продолжает волновать митературоведов, а вместе с ними - и читателей криминальной митературы.

$$
* * *
$$

КАассический Аетектив - особый жанр, отчетливые границы которого очерчивает Кириленко в большом поле криминальных произведений.

Представление о том, что в сюжетной основе этого типа митературы межит преступление, является общим местом. ОАнако же Кириленко показывает, что преступление в связке с расследованием бывает самых разных видов: «совершенное преступление и его расследование (или разгадка как теоретической задачи) размичными типами слеАователей»; «совершенное преступиение и месть за него»; «готовящееся преступиение и усилия жертвы избежать ими преступника - совершить его»; «становление преступника или борца с преступностью»; «повсеАневная жизнь преступника или борца с преступностью и т. А.» (37). От того, какое преступмение и каким образом оно расследуется в произвеАении, зависит его жанровая структура.

Жанров криминальной митературы, по мнению исследовательницы, Аовольно много, оАнако практики точного их определения в (российском) митературовеАении нет. Поэтому в конце монографии 
ее автор помещает список конкретных и хорошо знакомых мюбитемям криминамьной митературы произведений, разАеленный по жанровым разновидностям (c. 229-242).

К классическому Аетективу, вопреки общепринятому мнению, отнесены Аалеко не все произведения Артура Конана Аойма, Агаты Кристи, ЭАгара По и Аругих известных писателей. Так, например, Трава смерти ики Синял герань Кристи преАлагается рассматривать как «детективный ребус», а не как классический Аетектив, равно как и Тайну Мари Роже По. К жанру «авантюрное расследование» (подробнее о нем - позже) отнесены три романа Габорио, значительное количество романов Бориса Акунина о Фандорине и романов Кристи (классических Аетективов, по мнению Кирименко, у Кристи 40, а «авантюрного расследования» - 51), сюда же приписаны некоторые произведения об Арсене Аюпене Мориса Аеблана, рассказы Честертона и т. А.

Определяя место классического Аетектива в митературе, исследовательница начинает отсчет с эпического рода в цемом, выдемяя в нем область авантюрной митературы. ОАин из ее видов называется криминальная митература, которая, в свою очереАь, подразделяется на Ава подвиАа - криминальная китература расследования и все остальные произведения, гАе слеАствие не изображено. Внутри криминальной митературы расследования мы и находим кмассический Аетектив.

$$
* * *
$$

Исследование Кириленко проведено при помощи жанрово-генетического метода. Изучение кмассического Аетектива в этом ключе, конечно, уже проводилось и ранее, однако зачастую без учета важных генологических принципов. Такие исслеАования и их результаты Кириленко критикует в своей монографии. Она пишет:

В первом случае „Аетектив” преАстает в виде своеобразного Аерева, от которого отходят ветви: классический Аетектив; крутой Аетектив; шпионский роман и т. А. Во втором случае „Аетектив” наделяется способностью радикально менять свою структуру, приспосабливаясь к изменению социальных и прочих условий: был классический Аетектив, но наступили более „жесткие” времена, и он стал крутым. [...] Сюда же можно отнести метафору М. Тугушевой о „взорванной галактике”: „классический Аетективный роман очень изменился и породии Аругие разновидности”; „киассический детектив - как бы взорвавшаяся галактика, и вот результат взрыва - “беззаконные“ кометы (с. 28).

Автор монографии совершенно справеАливо называет образование нового жанра «сложнейшим процессом», не зависящим непосреАственно от внелитературных реалий:

Ни один жанр, - утвержАает исследовательница, $-[. .$.$] не может образоваться$ из Аругого поА влиянием обстоятельств (хотя послеАние могут способствовать востребованности ики невостребованности того или иного жанра). Точно так же ни при каких социамьных, экономических и т. А. изменениях кмассический Аетектив не может переродиться в крутой, поскольку это Ава разных жанра, имеющих разАичное происхожАение (с. 29).

ОАнако исследовательница начинает свою книгу не с генезиса жанра, а с установцения жанрового инварианта.

Эта методика характерна Аля цемого ряда российских научных работ, особенно тех, чьи авторы явцяются учениками Натана Тамарченко. Именно на 
него ссылается Кириленко, обосновывая такую последовательность работы (c. 31), а также на работы Владимира Проппа (Морфология сказки): «Совершенно очевидно также и не требует никаких доказательств, что о происхождении какого бы то ни было явмения можно говорить мишь после того, как явление это описано» (цит. на с. 32). Аобавим к этому еще высказывание одного из самых глубоких российских теоретиков Александра Скафтымова, писавшего:

Если без теоретического рассмотрения внутреннего состава произведения мы не имеет факта, то очевидно, что генетическое обследование этих фактов совершенно немыслимо без предварительного теоретического уяснения. [...] Кроме того, пока не установлено и не закреплено внутреннее назначение той или иной поэтической формулы в Аанном произведении, всякая генетическая работа или сведется к чисто внешним номенкматурным, ничего не говорящим рядам, или будет ускользать как Аым из-под пальцев (Skaftymov 2007: 37-38).

Итак, опираясь на хорошо отработанную методику, Кириленко выстраивает такую последовательность рассмотрения поэтики кмассического детектива: сначала - описание инварианта исследуемого жанра (глава вторая), затем - его генезис (глава третья).

При описании инварианта исследовательница выясняет, что Аля жанровой типологии важнейшее значение имеет установление типа протагониста (сыщика). Именно поэтому разделы главы названы именами героев - «Авойственная природа Аюпена и его метода расследования», «Шерлок Хоммс. Неправимьный блюститель нормы», «Пуаро - наиболее классический сыщик», «Мисс Марпл как иной тип классического сыщика».
ЗАесь же, во второй главе, приводится очень мюбопытный аналитический материал, Аемонстрирующий неоднородность тех произведений, которые мы привыкли называть «классическим Аетективом».

Среди них, по мнению Кириленко, выделяется особый жанр - «авантюрное расследование». Такое обозначение не представляется удачным; заметим, однако, что имена исторических жанров («возникших и ставших традиционными в самой художественной практике» (Tamarchenko 2012: 7)) вообще реАко бывают удовлетворительными. В силу этого их труАно типологизировать и приводить к какому-то общему знаменателю, о чем пишет, например, Жан-Мари Шеффер в известной книге Что такое митературньй жанр? (Sheffer 2010: 64-78). Впрочем, вполне вероятно, что название «авантюрное расследование» мегко приживется в литературоведении.

Основоположником «авантюрного расследования» Кириленко считает Эмимя Габорио; в исследовательской митературе его обычно называют одним из основателей детектива.

Мысль об отличном от классического детектива жанре возникает у исследовательницы при анализе произведений об Арсене ет, значительно отличается от классического сыщика. Обратим также внимание на то, что исследовательница опубликовала свои размышиения поА заглавием Цикл М. Аеблана о Аюпене: полемика с шерлокхолмсовским каноном в качестве отдельной главы в уже упомянутой выше антологии «Поэтика зарубежного классического детектива».

Полагаю, что не следует в Аеталях пересказывать, чем же характеризуется классический детектив, какие его особенности взяты за основу в теоретической 
модели жанра. Это научный центр монографии; хотя инвариантные черты детектива изможены в разделе «ПреАварительные выводы», помещенном в самом конце второй главы.

Остановлюсь мишь на оАной бопытной детали. Кириленко обращает внимание на гротескный характер сыщиков, в частности, их внешности; она пишет, что Аля Шерлока Хоммса, например, характерны «гротескные крайности» (с. 68), в чисме которых «ястребиный нос» (в русских переводах это выражение редко переводится буквально), временами проявмяющиеся у сыщика животные черты - расширяющиеся нозАри, рык и т.А. Петр Моисеев, рецензирующий Поэтику зарубежного классического детектива, в которой, как мы упомянули, есть глава Кирикенко, резко возражает: "Столь же неудачны попытки автора найти »гротеск« в изображении внешности Холмса и Аюпена...” (Moiseyev 2020: 405). А межАу тем, именно эти переходы в описании героя от человеческих черт к животным как нельзя удачней скужат илАюстрацией к бахтинскому пониманию гротескного тела: “неготовое и открытое тело это $[\ldots]$ не отделено от мира четкими границами: оно смешано с миром, смешано с животными, смешано с вещами" (Bakhtin 2010: 37).

ОАнако тут кроется противоречие с утверждением Кирикенко о том, что “герой классического детектива также готовый и неизменный” (с. 147). ВеАь гротескный образ, связан, по Бахтину, с изменениями, с "незавершенной еще метаморфозой” (Bakhtin 2010: 34), с “отношением к времени” (ibid.: 35), и никак не может быть готовым. Как тогда совместить и объяснить гротескность и «готовость» классического сыщика?

В этой фигуре появцяется Авойственность, что и отмечает Кирикенко: она фиксирует родственность сыщика с плутом, с “Авойственной фигурой” (Tamarchenko 2008: 272), с его "гротескной телесностью” (ibid.: 273), “принципиальной нетождественностью себе” (ibid.: 274). Эта амбивалентность, безусловно, Аолжна разрушать изнутри “готовый” характер классического детектива.

В связи с этим, как кажется, намечается тенденция Аальнейшего изучения проблемы, поставценной в монографии Кириленко: как и почему в классическом, каноническом жанре вызревает гротескный, неготовый, романный образ и к чему это приводит?

Рискнем преаположить, что именно эта, отмеченная исследовательницей, гротескная природа классического сыщика (Шерлока Холмса) позволила создавать сиквелы - “продолжения" и переработки художественного материала, как, например, сериал Шерлок. ВклаА в развитие «шерлокианы» внесли и сын Аойла ААриан Малкольм Конан Аойл, и Ажон Аиксон Карр, и Стивен Кинг, и Борис Акунин с его Узницей башни (гАе Аейст-

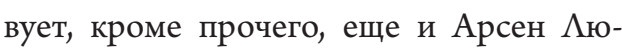
пен), и многие Аругие авторы. При том, что классический детектив как жанр уже исчерпал себя, все же мюбопытно, как проявляются его наследственные черты в Аругих произведениях.

$$
* * *
$$

Вторая часть исследования Натальи Кирикенко (и, соответственно, третья глава “Генезис классического детектива”) посвящена поиску истоков этого жанра. Исследовательница фокусируется только на одном, но "на самом важном источнике классического детектива - на Араме" (c. 43). Она так определяет методологические основания своих поисков: 
В качестве истоков митературного жанра могут рассматриваться, во-первых, уже Аавно сформировавшиеся к моменту его появления и во многих случаях уже и “застывшие” митературные жанры. А во-вторых, на ранних стадиях словесности $[. .$.$] - протожанры» (с. 42).$

Этим утвержАением Кириленко отвечает тем исскедователям, кто в качестве истоков называет "не более ранние жанры, а философское течение” (с. 42), а также “основателей жанра” (т. е., авторов произведений) (с. 43).

Перечислю конспективно основные выводы размышлений Кириленко. Она опровергает ставшее почти общим местом преАставление о генетическом схоАстве и даже родстве классического Аетектива и трагедии. Сопоставмяя Аетектив и классическую Араму, исследовательница выявмяет целый ряА схожих структурных признаков, а прежде всего - единство Аействия. В Араме оно проявцяется, по мнению Кириленко, в "необходимости каждого эпизода и отсутствии мишних" (c. 139), в “непрерывности действия и отсутствии парамлельного сюжета" (с. 142), в “ограничении роли скучая" (с. 143), в "невозможности $[\ldots]$ изображать оАновременно происходящее с разными персонажами в разных местах“ (с. 145). Сближает классическую Араму и классический детектив “сразу очерченный круг лиц” (с. 145) и притом круг ограниченный, особенности построения Аиалогов и вставных текстов, “готовый и неизменный герой” (с. 147).

ОАнако Кириленко не ограничивается сопоставлением детектива с трагеАией и Арамой, а неожиданно и довольно убеАительно доказывает, что истоком классического детектива можно и нужно считать комедию. Наиболее показательные аргументы и им^юстрации межат в области субъектно-речевой структуры этих Авух жанров. Комедия, утвержАает исследовательница, прямо противоположна трагеАИи, гАе межАУ героями ПосмеАовательно происходит "обмен монологами"; Аля комедии же, наоборот, “характерно перебивание, комментарии по ходу чужой речи, более того, передразнивание как чужих монологов, так и реплик противника в Аиалоге” (с. 149), их “взаимодействие и взаимоосвещение”, а порой и “комическое непонимание” (с. 151). Все эти признаки мегко обнаруживаются и в кмассическом Аетективе (хотя непонимание зАесь, конечно, не всегаа комично).

Кроме того, комеАия, в отличие от трагедии, рационамьный жанр, но при этом игра "составмяет самую суть и Авижущую сику” (с. 155), как и в кмассическом детективе. Не менее значимо Аля комедии (и Арамы) понятие нормы, а "в классическом детективе восстановление нормы отражает циклическую схему сюжета, обрамляющую кумулятивную” (c. 156).

Таким образом, один из важнейших источников классического детектива комедия, которая Аиалогична, связана с площадным театром и карнавальной традицией, т. е. эстетикой гротеска. Не это ли внутреннее ядро классического Аетектива, обусловленное его происхождением, стало одновременно и причиной его разрушения?

$$
* * *
$$

В закмючение нашей рецензии нужно отметить особую роль научных приложений к монографии, включающих подробнейшие, на несколько страниц, таблицы и схемы, в которых, как точно заметила Н. В. Аесогор, опубликовавшая в журнаме „Новый филологический вестник” рецензию (Lesogor 2020) на монографию 
Кирикенко, обнаруживается мюбопытное скрещение научной точности и занимательности, что, по мнению рецензентки, предвещает плодотворное развитие исследований детектива и в целом криминальной митературы: “Кто знает, не окажутся ми эти занятные детали системными элементами будущих исследований криминальной митературы?” (ibid.: 368).

\section{Библиография}

Bakhtin, Mikhail 2010. Sobraniye sochineniy. V 7 t. T. 4 (2). Moskva: Yazykislavyanskikh kul'tur.

Lesogor, Natal'ya Natanovna 2020. "Klassicheskiy detektiv kak predmet literaturo- vedcheskogo analiza”. Novyy filologicheskiy vestnik 3 (54): 365-369.

Moiseyev, Petr 2020. "Ot Dzheyn Osten do »Fantomasa «: Rets. na kn.: Poetika zarubezhnogo klassicheskogo detektiva. Moskva, 2019”. Novoye literaturnoye obozreniye 2 (162): 402-407.

Skaftymov, Aleksandr 2007. Poetika khudozhestvennogo proizvedeniya. Sost. Valeriy Prozorov [\&] Yuriy Borisov. Moskva: Vysshaya shkola.

Sheffer, Zhan-Mari 2010. Chto takoye literaturnyy zhanr?. Moskva: Yeditorial URSS.

Tamarchenko, Natan 2008. “Trikster”. W: Natan Tamarchenko (red). Poetika. Slovar' aktual'nykh terminov i ponyatiy. Moskva: Izdatel'stvo Kulaginoy; Intrada.

2012. Teoriya literaturnykh zhanrov. Moskva: Akademiya. 